\title{
A teoria das nulidades no Direito Português e Brasileiro
} Trabalho apresentado no Curso de Mestrado - disciplina Direito Comparado, $1^{\circ}$ semestre de 1988.

\section{Sandra Della Pola da Silya \\ Mestranda}

Seja como for, é à técnica legislativa que toca discriminar as causas de nulidade e as de anulabilidade para que se observem os dois regimes, internos ao plano da validade, aten didas modificasóes que se entendam, na lei. indispensáveis. Quase sempre, essas modificaçoes de limites entre as duas espécies de invalida de provém de causas bistóricas, de pedaços de sistemas jurídicos diferentes (e.g., o romano, o germânico, o canônico, o toraleiro), que perduram no sistema jurídico vigente.

\section{Pontes de Miranda}

\section{SUMÁRIO}

Introdução; 1. Nulidade no Direito Português e Brasileiro; 1.1. Nulidade no Direito Português; 1.2. Nulidade no Direito Brasileiro; 2. Anulabilidade no Direito Português e Brasileiro; 2.1. Anulabilidade no Direito Português; 2.2. Anulabilidade no Direito Brasileiro; Conclusão; Bibliografia.

\section{Introdução}

O presente trabalho tem por fim analisar, buscando uma comparação, a Teoria das nulidades no Direito Português e Brasileiro.

A complexidade que envolve um traba Iho comparativo, bem como a especial ligação entre as duas nações, requer se faça referência a alguns dados do processo histó rico-jurídico de Portugal e do Brasil, eis que o presente está alicerçado no passado, invariavelmente.

A história jurídica portuguesa, a rigor, registra dois códigos: o primeiro datado de 1867 e o segundo datado de 1966.

Contudo, não é possível omitir o movimento legislativo iniciado desde o século XIII, bem como o primeiro arcabouço jurídico surgido nos meados do século $\mathrm{XV}$, isto é, as Ordenações Afonsinas, representando a primeira codificação oficial ${ }^{1}$, seguidas pe- las Ordenações Manuelinas e Filipinas, respectivamente em 1521 e 1603 , que, de certa forma, reproduziram a primeira.

Logo, compreende-se que a vida portuguesa esteja, desde há muito, estruturada, disciplinada, de alguma forma. Ou seja consubstanciada numa norma escrita, o que facilita a idéia de codificação.

$E$ bem verdade que a afirmativa acima, qual seja, a da estruturação, deve ser vista com reservas no que diz respeito, sobretudo, ao Direito Privado, consagrado no Livro IV e, vez que outra, esparsas nos restantes, pois que as Ordenações radicaram dificuldades e defeitos intransponíveis. Por exemplo, as Ordenações Filipinas, desde a sua promulgação, apresentaram-se obsoletas, reproduzindo um sistema ultrapassado ${ }^{2}$.

Evidentemente, isto implicou a ampliação da legislação extravagante que, mesmo

$$
\text { R. Fac. Direito UFRGS, Porto Alegre, 9(1): 234-247, nov. } 1993
$$

sujeita aos defeitos e obscuridades que não satisfizeram as necessidades, salvo exceções notáveis, registravam o novo espírito da época. Isto é, o liberalismo/individualismo que permeava o mundo, adentrando, assim, Portugal, revolucionando a política, a economia e, conseqüentemente, o organismo jurídico.

O marco, que não pode ser esquecido, no critério integrativo, superador das lacunas da lei, e, também interpretativo, nasceu em 18 de agosto de 1769 , ou seja, a famosa Lei da Boa Razão, que se refletiu no Brasil.

A técnica consagrada nesta norma consistia na indicação das fontes subsidiárias, superando o critério anterior que remetia aos textos romanos, bem como à doutrin em desprestígio à lei ou aos usos legítimos. Agora, subsidiariamente utilizar-se-ia a "bo razão" ${ }^{\prime 3}$.

Supera-se, igualmente, a interpretação restritiva da lei pátria em confronto com o direito romano, adotando-se novos critérios. ${ }^{4}$

Esta norma criadora abriu e possibilitou a ação jurisprudencial ${ }^{5}$. E a ação da jurisprudência aliada ao espírito liberal, sem dúvida, desencadeou, quase espontaneamente, a primeira codificação portuguesa, que é o Código Civil Português de $1^{\circ}$ de julho de 1867. Na verdade, nasceu com a promulgação do Decreto de 9 de agosto de 1850 que encarregou o Visconde de Seabra (Antonio Luís Seabra) de redigir o projeto. O que significa dizer foi obra de uma só mão, da porque é chamado "Código de Seabra".

Os defeitos de origem, radicados na complexidade da matéria e no fato de um único homem a confeccioná-la; a necessidade de esclarecer pontos obscuros face à vigência prolongada e às mudanças sociais, que determinaram a promulgação de vários diplomas em separado que registravam o pensamento da nova época que, em muito, superou o individualismo do passado para dar lugar a uma visão mais sociativa, na consagração dos direitos comunitários, aliás, adotados pela Constituição; bem como a imprecisão técnica do Código de 1867, que estava longe de ser considerado adequado, justificaram a promulgação do Decreto 33.908 de 4 de setembro de 1944, e seu amplo relatório, dispondo a elaboração de um projeto de revisão geral do Código Civil. Em seguida, através da Portaria $\mathrm{n}^{\circ}$ 10.756 de 10 de outubro de 1944 , era entregue tal mister a uma Comissão de Jurisconsultos.

Posteriormente, em 1966, a promulgação do segundo Código Civil Português, em vigor até hoje, inspirado numa visão mais social. É lugar comum dizer que a história do Brasil está invariavelmente, ligada a Portugal. Assim também no âmbito jurídico.

Ainda que fosse possível afirmar a autonomia brasileira a partir de 1916, com o Código Civil, ter-se-ia que admitir que uma codificação é fruto de todo um processo histórico. E, neste passo, o arcabouço histórico brasileiro constitui-se das Ordenações Portuguesas que vigoraram no Brasil desde a descoberta até a efetiva entrada em vigor do Código. O que vale dizer, tiveram maior duração no Brasil do que, propriamente, em Portugal.

E, mesmo que a codificação atual tenha superado os conceitos do passado, a simili. tude do processo de vida, dos fatores históricos, explicam e substanciam a influência. O que não se pretende afirmar sejam iguais, mas, tão somente, que não é possível negar semelhanças (e até diferenças) entre dois organismos jurídicos em que, por longo tempo, foram um só.

Ainda que separadas as duas nações pela independência do Brasil, prosseguiu este sob a égide da legislação oriunda de Portugal. A bem da verdade, muito mais tradicionalmente portuguesa do que na Pátria Mãe, eis que o Brasil, mais distante da ebulição das novas idéias, pode absorvê-las com maior clareza e harmonia.

Um exemplo do conservadorismo está na Consolidação das Leis Civis de Teixeira de Freitas (1858), diz-se conservador não retrógrado. Esta Consolidação teve o respeito de um verdadeiro código, até porque não fora possível a feitura do código que só aparecerá em $1^{\circ}$ de janeiro de 1916, quando então as tentativas lograrão êxito: e final- 
mente tem-se o Código Civil Brasileiro - Lei 3071.

Dentro deste processo histórico da ligação destas duas nações e de suas vidas internas, ora unidas, ora independentes mas interligadas, é possível compreender semelhanças e diferenças, no presente, nas codificações.

Entre as semelhanças está a Teoria das Nulidades com nuances específicas, que serão abordadas. Partem ambos do mesmo ponto, isto é, transgressão de norma imperativa.

Todavia, a guisa de introdução, deve ser salientado, mesmo que ainda não compreendida pela doutrina em geral e não assimilada pela legislação, o ensinanento de Pontes de Miranda que, em 1954, já alertava para a necessidade de atualizar e discernir a aplicação das expressões, no que diz respeito ao tema, cuja tradução, desde o direito romano, vem causando obstáculos. Demonstrou que, para a época, Ato Jurídico $=$ Ato válido, logo Nulidade = Inexistência. $O$ tratadista entende não ser possível equiparar invalidade e ineficácia. Desta afirmativa, cria a teoria dos três planos de análise da questão, qual seja: o plano da existência, isto é, o ato adentra o mundo do direito ou não; o plano da validade ou invalidade, isto é, o ato adentrou o mundo do direito, mas é preciso verificar os requisitos de validade, é neste momento que cumpre a denominação ato jurídico; o plano da eficácia, isto é, o momento da produção de efeitos, é a verificação dos fatores de eficácia.

$\mathrm{O}$ entendimento de Pontes permite solucionar inúmeros buracos que a doutrina dos dois países não tem podido explicar, uma vez que, algumas vezes, o direito confere efeitos ao ato nulo.

Outras vezes, o direito admite seja sanado o nulo, logo não é possível equiparar os planos de análise, e confundi-los.

$O$ estudo a seguir pretende evidenciar este instituto jurídico a partir do processo histórico que se salientou acima, para demonstrar a oportunidade de um exame mais profundo na Teoria das Nulidades.
Para tanto, no primeiro item, analisar-seá a Nulidade no Direito Português e Brasileiro, subdividido em dois momentos destinados, o primeiro a Portugal, e o segundo, que possibilitará o confronto, para o Brasil. O segundo item analisará a Anulabilidade no Direito Português e Brasileiro, seguindo a mesma sistemática. Para, então, propiciar a conclusão.

\section{1 - Nulidade no Direito Português e \\ Brasileiro}

1.1. Nulidade no Direito Português

A questão deve ser examinada nos Diplomas legais de 1867 e 1966.

A doutrina refere, ao analisar o Código atual, que este melhor disciplina a matéria, eis que $o$ anterior não previa regramento genérico e sim noções esparsas ao longo do texto.

Não resta dúvida de que o Código mai recente apresenta soluções superiores como por exemplo, o problema da oponibilidade da nulidade e da anulabilidade a terceiros ${ }^{6}$

Todavia, não é possível afirmar que Código de Seabra, porque apresentou disposições esparsas, não possuísse uma regra genérica, eis que o artigo 10 esboçava o norte da matéria.

Logo, percebe-se que, na verdade, o legislador do passado, ao disciplinar a questão em outros dispositivos, procurou reforçar o en tendimento materializado no art. 10, eis que especifica as formalidades externas essenciais ${ }^{7}$

$\mathrm{Na}$ verdade, não há uma modificação acentuada na linha de análise deste tema nulidades. Isto é, a regra contida no artigo 10 do Código de 1867 está mais ou meno presente no artigo 294 do Código de 1966 uma vez que o ponto de partida é idêntico, guardadas as devidas proporções, ou seja, transgressão de norma imperativa.

Algumas considerações merecem relevo nestas duas fases:

A) Código de 1867:

"Art. 10: Os atos praticados contra a disposição da lei, quer esta seja proibitiva, quer preceptiva, envolvem nulidade, salvo nos casos em que a mesma lei ordena o contrário.
Parágrafo único. Esta nulidade pode, contudo, sanar-se pelo consentimento dos interessados, se a lei infringida não for de interesse e ordem pública".

$\mathrm{Na}$ análise deste Diploma legal, observase a falta de cuidado no emprego das expressões, vez por outra substituindo a palavra nulidade por anulabilidade.

Aliás, nesta primeira fase, não raro, a doutrina não distinguiu a validade da eficácia. Equipara o nulo ao inexistente ${ }^{8}$

Igualmente, identifica a nulidade com a anulabilidade? ${ }^{9}$. Todavia, o Decreto $\mathrm{n}^{\circ} 1 \mathrm{de}$ 25 de dezembro de 1910 registra a possibilidade de sanação do ato nulo. E o caso, por exemplo, do casamento de tutor e tutelado sem a prestação de contas legalmente exigida que, de regra, dá lugar apenas a considerar-se o regime de bens como sendo o da separação de bens, e a aplicação de uma multa ao marido, mas fica mantido o casamento ${ }^{10}$.

Outras vezes, a decretação da nulidade não é sanção suficiente e pode ser acrescida de outras penalidades:

a) perdas e danos - acrescenta-se à decretaça de nulidade ainda a indenização. Ex. $\S 2$ do art. 697: "Nos casos em que tenha havido dolo ou má fé, há obrigação de indenização".

b) pena criminal: acrescenta-se a aplicação de uma pena. É o caso, por exemplo, do crime de burla, do art. 1555.

c) Às vezes, não há anulação do ato cumula-se a indenização e a responsabilidade penal, é o caso do artigo 1579.

Logo, é preciso observar que, de certa forma, a nulidade gera efeitos.

O Código de Seabra mereceu severas crí ticas, eis que, inicialmente, foi interpretado como querendo estender a todo o campo do Direito Privado o formalismo exagerado ${ }^{11} \mathrm{e}$, portanto, os tribunais não o aplicariam ${ }^{12}$.

Contudo, tal não aconteceu, e a regra genérica do artigo $10^{\circ}$ foi a inspiradora de soluções inúmeras da vida prática.

Outras questões foram levantadas ao próprio Visconde de Seabra, como, por exemplo, Morais de Carvalho indagou sobre a deliberação de um conselho de família integrado por um incapaz. $O$ autor do projeto entendeu que tal deliberação seria nula. Esqueceu-se, porém, que a deliberação do conselho só estaria eivada de nulidade caso o vogal incapaz fizesse parte da maioria, é o que preceitua o artigo $207, \S 3^{0}{ }^{13}$.

Por fim, coube aos doutrinadores da época indicarem os limites do artigo $10^{\circ}$ e seu parágrafo único, ou seja, conceituar a norma preceptiva, proibitiva e dispositiva, aliás, ensinamentos que transcenderam aos dias de hoje.

Convém referir, de outra banda, que o fato de os juristas identificarem no mesmo plano validade e eficácia resultou numa gradação do conceito de nulidade, ou seja, nulo é o reduzido a nada, privado de efeitos, logo deduziram três escalas de valores para a nulidade:

a) inexistência legal: a mais grave das nulidades, porque falta requisito essencial à existência jurídica ${ }^{14}$;

b) a nulidade absoluta ou de pleno direito: praticado em desacordo com a norma proibitiva ou preceptiva;

c) anulabilidade: abordar-se-á oportunamente.

Ainda dentro do espírito do artigo $10^{\circ}$ é oportuno verificar a revalidação e a conversão, explica-se, desde já, que serão assuntos reavaliados após as breves considerações ao Código de 1966. A priori será registrado, todavia, peculiaridades a propósito do artigo mencionado.

Observa-se que, conforme o disposto no artigo $10^{\circ}$, o acordo de vontades pode revalidar, desde que a norma infringida não seja de caráter público.

Ou seja,' é possível revalidar o nulo, em alguns casos, mas se exige a convergência de vontades. Por exemplo, é possível declararse na nova escritura de uma sociedade que já foi declarada inexistente, que a mesma é tida por existente desde a data do contrato anterior. O mesmo é vedado em matéria de casamento.

Igualmente, é permitida a conversão dos atos inexistentes e nulos. Isto é, o aproveitamento, no todo ou em parte, quando contiver elementos suficientes para a feitura de 
outro ato que satisfaça o interesse das par-

Entretanto, afirma-se que não há dispositivo legal que autorize a conversão, excecão feita a alguns dispositivos para aproveitamento específico. Porém há regra genérica que pode ser aplicada para possibilitar a conversibilidade dos atos jurídicos, é aquela contida no art. 16:

"Se as questões sobre direitos e obrigações não puderem ser resolvidas, nem pelo texto da lei, nem pelo seu espírito, nem pelos casos análogos, prevenidos em outras leis, serão decididas pelos princípios de $\mathrm{di}$ reito natural, conforme as circunstâncias do caso".

B) Código de 1966:

"Art. 285 - Na falta de regime especial, são aplicáveis à nulidade e à anulabilidade do negócio jurídico as disposiçōes dos artigos subseqüentes".

"Art. 286 - A nulidade é invocável a todo o tempo por qualquer interessado e pode ser declarada oficiosamente pelo tribunal".

"Art. 294 - Os negócios jurídicos celebrados contra disposição legal de caráter imperativo são nulos, salvo nos casos em que outra solução resulte da lei".

Há uma evolução doutrinária na questão da inexistência/invalidade, embora prossiga a discussão da oportunidade ou não de se considerar como categoria específica a inexistência jurídica ${ }^{16}$.

$O$ aprofundamento da questão está calcado, exatamente, no fato de que, algumas vezes, o direito reconhece efeitos ao ato nulo. Logo, não pode haver confusão entre nulidade e inexistência, e, sim, serem planos distintos, o que, aliás, não é concluído com segurança, porque o direito não pode emprestar direitos ao nada.

Seja como fora, as circunstâncias estão a exigir um posicionamento, o mesmo vale para o Brasil.

Objetivamente, consagrado na lei, a inexistência aliada ao instituto do casamento. Segundo Mota Pinto, noção absorvida do Direito Francês ${ }^{17}$. O artigo 1628 regula os casos de inexistência e o artigo 1630 dispõe que tais situações não produzem efeitos,
2) não pode ser sanada, nem mediante o transcurso do tempo, isto é, alegável a todo tempo, imprescritível. Evidentemente, valem as observações já mencionadas, especialmente a nota de rodapé $\mathrm{n}^{\circ} 6$;

$\left.3^{\circ}\right)$ não pode ser sanada mediante confirmação, embora admitia a renovação. Isto é, o ato nulo, ao ser renovado, é, na verdade, novo contexto com efeitos ex nunc, mesmo que, nas relações inter-partes, fique estipulada a eficácia retroativa. Todavia, confirmação é negócio unilateral com efeito retroativo. Logo, face à gravidade da lesão às normas jurídicas, $o$ ato nulo não pode merecer confirmação;

$\left.4^{\circ}\right)$ não produz os efeitos visados;

$\left.5^{\circ}\right)$ a nulidade admite a conversão, ou seja, a possibilidade de ser aproveitado, no todo ou em parte, quando contiver elementos suficientes para a feitura de outro negócio;

$\left.6^{\circ}\right)$ a nulidade não é incompatível com a teoria da redução dos negócios jurídicos;

$\left.7^{\circ}\right)$ a declaração de nulidade tem efeito retroativo e exige a restituição de tudo que tiver sido prestado ou valor equivalente.

1.2. Nulidade no Direito Brasileiro:

"Art. 145: É nulo o ato jurídico:

I - Quando praticado por pessoa absolutamente incapaz (art. 5\%).

II - Quando for ilícito ou impossível o seu objeto.

III - Quando não se revestir a forma prescrita em lei (art. 82 e 130).

IV - Quando for preterida alguma solenidade que a lei considere essencial para a sua validade.

V - Quando a lei taxativamente o declarar nulo ou lhe negar efeito".

"Art. 146: As nulidades do artigo antecedente podem ser alegadas por qualquer interessado, ou pelo Ministério Público, quando lhe couber intervir.

Parágrafo único. Devem ser pronunciadas pelo juiz, quando conhecer do ato ou dos seus efeitos e as encontrar provadas, não the sendo permitido supri-las, ainda a requerimento das partes".
Pela leitura do já exposto, percebe-se a similitude do Direito Português com o Brasileiro. Evidentemente, guardadas as observações feitas na introdução deste trabalho, no que diz respeito ao ensinamento de Pontes de Miranda, isto é, a nulidade e a anulabilidade, devem ser analisadas no plano da validade, ou melhor, distinguindo-se pela maior ou menor gravidade de défice, mas internamente no plano da validade ${ }^{18}$.

A doutrina clássica, porém, ainda permanece em designações muito assemelhantes aos portugueses ${ }^{19}$, ou melhor, a nulidade, dita absoluta, existe ao lesar o interesse público, daí porque a violenta reação que não é só de grau, mas de natureza ${ }^{20}$.

Assim, a nulidade é sanção, eis que o ato fendeu a pre-determinação legal, ou seja, desrespeitou a Ordem Pública, transgrediu a norma cogente e imperativa ${ }^{21}$.

Com relação ao emprego das expressões, bserva-se a mesma impropriedade referida pelos doutrinadores portugueses, eis que 0 legislador pátrio também, vez por outra, não conseguiu fugir à confusão.

E, encontra-se na doutrina brasileira, porque parte o estudioso da transgressão à norma de caráter público, a tendência a definir as nulidades a partir da gradação da ineficácia, gerando três categorias, quais sejam, os atos nulos, anuláveis e inexisten$\mathrm{es}^{22}$

Para facilitar a comparação, que é o objeto deste estudo, enumeram-se as caracterís ticas da nulidade no Direito Brasileiro, estabelecendo o confronto.

$\left.1^{9}\right) \mathrm{O}$ ato nulo é insanável. Logo, não pode ser ratificado, isto é, a vontade das partes não tem o poder de revalidá-lo. Nem o juiz tem tamanha autoridade, ainda que a requerimento das partes.

Igualmente ao Direito Português a realidade expressa na lei contesta a tese exposta, eis que, a exemplo da legislação portuguesa, o Código Civil Brasileiro admite a sanação do nulo no art. 208, por exemplo:

"E também nulo o casamento contraído perante autoridade incompetente (arts. 192, 194, 195 e 198). Mas esta nulidade se con- 
siderará sanada, se não se alegar dentro em dois anos da celebração".

Por outro lado, como regra geral, sem dúvida, o ato nulo é insanável nas duas legişlações. Muito embora fique claro a necessidade de se aprofundar os estudos par estabelecer critérios mais harmônicos, pois que, é evidente, ao considerar-se o critério do saneamento atribui-se efeitos ao nada ${ }^{23}$

Quanto à ratificação, ou seja, convergência de vontades para dar cumprimento ao ato nulo é vedada na legislação brasileira, ao contrário da portuguesa que a admite com as observações já referidas. Com maio razão, é óbvio, não é admissível na codificação pátria a confirmação do ato nulo, agora, em semelhança a Portugal.

Desta questão surge conseqüência interessante face à diferença da regra geral, ratificação, em relação à capacidade do agente, que possui disciplinação diferenciad nos dois países, ou seja, a incapacidade ab soluta no Brasil é causa de nulidade absoluta (art. $145 \mathrm{CCB}$ ), mas em Portugal é caus de anulabilidade, bem como não há distin ção entre relativa e absoluta (artigos 687 688 do Civil de Seabra e artigo 125 do Código Civil atual). Assim, uma vez que Direito Brasileiro não admite a ratificação do ato nulo, a incapacidade absoluta do agente não tem remédio.

2) $\mathrm{O}$ ato nulo é imprescritível, isto é não é convalidado pela prescrição.

A doutrina brasileira vem fazendo observação, à semelhança da portuguesa, ainda que não idênticas as soluções. Isto é, a partir da constatação de que a prescritibilidade é a regra e, no resguardo do interesse socia e da segurança dos negócios, têm os estudiosos acrescentado a afirmativa acima à indicação do art. 177 do Código Civil Brasileiro dizendo que o ato nulo não é invulnerável prescrição como regra geral, mas o melho entendimento é que pode ser atacado a qualquer tempo, desde que alegado ${ }^{24}$

$3^{\circ}$ ) Pode ser alegado por qualquer interessado ou ex officio pelo juiz.

Idêntico o posicionamento.

$\left.4^{\circ}\right)$ Não produz efeitos.

Idêntico o posicionamento.

240 $\left.5^{\circ}\right)$ Quando à conversão, o Direito Brasileiro está, ainda, correspondendo à primeira Codificação Portuguesa, eis que não existe na legislação um dispositivo que autorize a conversibilidade dos negócios jurídicos. Esta, quando acontece, tem sido introduzida pela ação jurisprudencial, embasada nos princípios gerais de direito.

Parece que, ao vigorar a tese do Projeto de Código Civil no 634/75, o artigo 168 solucionará o impasse, introduzindo o instituto da conversão dos negócios jurídicos.

$\left.6^{\circ}\right)$ A nulidade não é incompatível com a teoria da redução dos negócios jurídicos, aliás disciplinada, como já visto, no Código Civil Português de 1966, no artigo 292; e no Código Civil Brasileiro, no artigo 153:

"A nulidade parcial de um ato não o prejudicará na parte válidade, se esta for separável. A nulidade da obrigação principal implica a das obrigações acessórias, mas a destas não induz a da obrigação principal".

$\left.7^{\circ}\right)$ A declaração de nulidade tem efeito retroativo e exige a restituição de tudo o que tiver sido prestado ou a indenização equivalente. É regulada, em Portugal, pelo artigo 289 do Código Civil de 1966 e no Direito Brasileiro pelo artigo 158 do Código Civil:

"Anulado o ato, restituir-se-ão as partes ao estado, em que antes dele se achavam, e não sendo possível restituí-las, serão indenizadas com o equivalente".

$8^{\circ}$ ) Quando à restituição feita pelo menor, observa-se que o Direito Brasileiro corresponde ao exposto no Código de Seabra, ou seja, a obrigação de restituir é ligada à prova de locupletamento. Este dispositivo não encontra guarida atualmente em Portugal. No Brasil está radicado no artigo 157 do CCB:

"Ninguém pode reclamar o que, por obrigação anulada, pagou a um incapaz, se não provar que reverteu em proveito dele a importância paga".

$\left.9^{\circ}\right)$ Quanto ao objeto, a exigência contida no artigo 145, II, do Diploma Brasileiro está em consonância com os artigos 643 e
669 do Código de Seabra e artigo 280 do Código atual.

$10^{\circ}$ ) Quanto à forma, preceito estabelecido no artigo 145, III e IV, do Código Civil Brasileiro, está em consonância com o artigo 686 do Código de Seabra e 220 do atual Diploma Português.

Evidentemente que ao particularizar a matéria, encontram-se diferenças na abordagem das nulidades, como, por exemplo, com relação à capacidade do agente. Mas isto não é objeto do presente estudo, razão por que pode-se afirmar que, em linhas gerais, as semelhanças são acentuadas, porque partem do mesmo ponto, ou seja, nulidade é transgressão de norma de caráter público.

2 - Anulabilidade no Direito Português e Brasileiro

2.1. Anulabilidade no Direito Português

Conforme ficou entendido anteriormente, quando a norma violada não é de ordem pública, está presente a nulidade relativa, expressão alterada no presente para anulabilidade. Por conseguinte, esta não é tão grave como a nulidade, embora o ato seja, também, viciado ${ }^{25}$

Esta figura mereceu tratamento nas duas Codificações Portuguesas, sendo que o atual introduziu alterações no sistema das anulabilidades. Cumpre examinar alguns elementos particulares do Código de Seabra e do de 1966.

A) Código de 1867:

"Art. 10, parágrafo único - Esta nulidade pode, contudo, sanar-se pelo consentimento dos interessados, se a lei infringida não for de interesse e ordem pública".

A doutrina, ao cogitar das causas de anulabilidade, aponta (até os dias atuais) a incapacidade do agente ou a ocorrência de vício de vontade (erro, dolo, violência) ${ }^{26}$. Por outro lado, estas causas são inibidoras da renúncia prévia, vedada pela lei, quer para a proteção dos incapazes, quer pelo caráter ilícito do dolo e da violência. A regra está prevista no art. $668,1^{a \underline{a}}$ parte: "De futuro não será lícito renunciar previamen- à nulidade, proveniente do dolo ou da coação".

A rescisão, entretanto, está na esfera dos interesses privados, e, portanto, fica no arbítrio das pessoas em favor de quem são criadas, que podem argüi-las, cessada a incapacidade ou o vício, é o que prevê o artigo 696:

"O contrato nulo, por incapacidade, erro ou coação, pode ser ratificado, tendo cessado o vício, ou o motivo da nulidade, e não ocorrendo outro que invalide a mesma ratificação".

Observa-se que a lei restringe aos participantes do negócio a referida rescisã ${ }^{27}$.

Mas o aspecto que assume papel especial m matéria de anulabilidades é o saneamento, uma vez que, seja pela ratificação, seja pelo decurso de tempo, o ato jurídico anulável pode ser entendido como válido ${ }^{28}$. O artigo 10 in fine concede permissão, mas não regula a confirmação, isto é, a lei admite a confirmação, inclusive alguns dispositivos a mencionam, todavia não a contempla em artigo especial e, sim, ao longo do código, e não pode prejudicar terceiros ${ }^{29}$.

Igualmente, o decurso do prazo é causa saneadora prevista no Capítulo VIII - Da rescisão dos contratos, ou seja, cinco anos incapacidade e um ano para os vicios da vontade.

Quanto aos efeitos da anulabilidade, vale o mesmo que por ocasião da nulidade, ou melhor, a regra é voltar à situação anterior, indenizando, se for o caso. Porém o problema a ser enfrentado, novamente, é a situação do incapaz que não está obrigado a restituir, salvo o caso de locupletamento. Da mesma forma, como referido, o atual Código alterou a situação.

B) Código de 1966:

"Art. 287. 1. Só tem legitimidade para arguir a anulabilidade as pessoas em cujo interesse a lei a estabelece e só dentro do ano subseqüente à cessação do vício que lhe serve de fundamento. 2. Enquanto, porém, o negócio não estiver cumprido, pode a anulabilidade ser arguida, sem dependência de prazo, tanto por via de ação como por via de excepção". 
A evolução é marcante com relação à anulabilidade no Código vigente e na doutrina, inclusive.

Como já mencionado, um assunto im portante, em se tratando de atos jurídicos anuláveis, face ao vício que carregam e, principalmente, porque não contrariam dispositivo de interesse, predominantemente, público, ou, na linguagem do Código, norma imperativa, é a teoria dos atos jurídicos em seus dois expoentes:

$\left.1^{\circ}\right)$ a confirmação, que recebeu dispositivo próprio no Código atual, o artigo 288

"Art. 288. 1. A anulabilidade é sanável mediante a confirmação.

2. A confirmação compete à pessoa quem pertencer o direito de anulação, e só é eficaz quando for posterior à cessação do vício que serve de fundamento à anulabilidade e o seu autor tiver conhecimento do vício e do direito à anulação.

3. A confirmação pode ser expressa ou tácita e não depende de forma especial.

4. A confirmação tem eficácia retroativa, mesmo em relação a terceiro".

Percebe-se, pelo $\mathrm{n}$ 4 do artigo acima, que o novo Código introduz importante inovação, ou melhor, apresenta a eficácia retroativa da confirmação mesmo em relação a terceiro $^{30}$.

$2^{\circ}$ ) O decurso de tempo, o novo Código inovou, igualmente, nesta matéria, eis que diminuiu o prazo para um ano, como mencionado no artigo 287, para os vícios da vontade em geral, igualmente, um ano em relação à incapacidade (art. 125) e três anos por ilegalidade matrimoniais (artigo 1687)

O Código de 1966 também é específico ao arrolar as pessoas que podem invocar anulabilidade, como se constata na leitura do artigo 287, supracitado. É bem verdade que outros dispositivos regulam esta matéria, como, por exemplo, os artigos 125,254 e 1687, e, portanto, o artigo 287 tem caráte genérico, na omissão, aplica-se a regra nele contida.

Também, na tentativa de aproveitar os atos jurídicos, embora não diga respeito à sanabilidade propriamente dita, está a con242 versão, que ganhou tratamento próprio no artigo 293, já comentado.

Ainda, como especialidade do Código vigente, deve ser salientado o $\mathrm{n}^{\mathrm{Q}} 2$ do artigo 287, eis que deixou clara a questão da imprescritibilidade do inadimplemento o que, no regime anterior, entendia a lei de regular, tão somente, para o caso da exceção de cumprimento.

Em síntese, são características gerais da anulabilidade no Direito Português, guardadas as nuances mencionadas:

19) Só pode ser alegada por pessoa dotada de legitimidade. Compreensível esta característica, uma vez que a anulabilidade pressupõe vício ou infração, mas não de norma que afete substancialmente a ordem pública, mas, sim, norma que regule interesse particular. Logo, há que estabelecer em lei estes interessados para que a própria lei não acabe por permitir o que busca evitar.

$\left.2^{\circ}\right)$ Produz o ato anulável, os efeitos, enquanto não anulado ${ }^{31}$. A doutrina trata o anulável como válido, eis que só será anulado pela manifestação do interessado ${ }^{32}$.

$\left.3^{\circ}\right)$ Não existe com relação a terceiros. Evidentemente, eis que a anulabilidade só pode ser alegada por determinadas pessoas. Portanto, ficam as demais excluídas, na de pendência de que os legitimados se manifestem. Veja-se a inovação no que diz respeito à confirmação (284. 4)

$\left.4^{\circ}\right)$ Pode ser sanada pela confirmação ou ratificação e pelo decurso do tempo. A ação saneadora é a grande característica do ato anulável $^{33}$, e constitui, a rigor, a regra ${ }^{34}$ Aliás, não poderia ser diferente face à definição de ato anulável e às exigências legais para argüí-lo.

Como primeira saneadora aponta-se confirmação, ou seja, a pessoa legitimada para alegar a anulação declara, unilateral mente ${ }^{35}$ aprovar o negócio viciado. Logo, a base da confirmação é a vontade do agente em confirmar o negócio, o que pressupõe o conhecimento do vício e do direito de anular o negócio. Sem dúvida, a conseqüência principal do ato confirmatório é a validação do ato jurídico, retroativamente, desde a origem, e pelo Código atual, alcançando terceiros sujeitos a indenização ${ }^{36}$.

A outra medida saneadora, aliás para to dos os males, é o decurso do tempo, ou seja, a não argüição dentro de um prazo estabelecido em lei opera a convalescença do ato.

$\left.5^{\circ}\right)$ A conversão - introduzida no Código atual; tem requisitos específicos para não ser confundida com outras figuras, o que normalmente ocorre.

$6^{\circ}$ ) A teoria da redução dos negócios jurídicos. Não há razão alguma para que a regra contida no artigo 292 não seja aplicada à anulabilidade.

$\left.7^{\circ}\right)$ São causas de anulabilidade os vícios de vontade, a incapacidade e todos aqueles que só interessam a determinadas pessoas, ou só por elas podem ser alegadas.

$\left.8^{\circ}\right)$ Tem efeito retroativo, devendo ser restituído ou indenizado. Atualmente, inclusive os incapazes.

Assim, a anulabilidade no Direito Português é, em regra, a infração à norma tuteladora de interesses predominantemente particulares, em conseqüência, recebendo tratamento mais brando.

\subsection{Anulabilidade no Direito Brasileiro}

"Art. 147. E anulável o ato jurídico:

I - Por incapacidade relativa do agente (art. $\left.6^{\circ}\right)$.

II - Por vício resultante de erro, dolo, coação, simulação, ou fraude (arts. 86 a 113)".

"Art. 148. $O$ ato anulável pode ser ratificado pelas partes, salvo direito de terceiro.

A ratificação retroage à data do ato".

"Art. 152. As nulidades do art. 147 não efeito antes de julgadas por sentença, nem se pronunciam de ofício. Só os interessados as podem alegar, e aproveitam exclusivamente aos que os alegarem, salvo o caso de solidariedade, ou indivisibilidade.

Parágrafo Único. A nulidade do instrumento não induz a do ato, sempre que est puder provar-se por outro meio".

Igualmente, em matéria de anulabilidade, verifica-se similitude com o Direito Português. Novamente, faz-se referência aos en- sinamentos de Pontes de Miranda, para quem o ato anulável é o válido que depende decretação que elimine seus efeitos, sujeito à prescrição da competente ação ${ }^{37}$.

Da mesma forma, a doutrina clássica não absorveu o ensinamento do jurista referido por isso, as definições aproximam-se das fá expostas por ocasião do Direito Portuja expo

Em verdade, os estudos comuns têm definido a anulabilidade como a ofensa a normas de interesse privado, ou seja, não se registra uma ofensa a interesse público, todavia poderá ter ocorrido prejuízo a uma das partes protegidas pelo ordenamento. Lo foria do ato anulável é proteger os interesses do particuanulave

Diz-se que o ato não é perfeito, mas o Dróntanto também no Direito Brasileiro o aspecto relevante da anulabilidade é a teoria da convalescença.

Enumeram-se as características da anulabilidade no Direito Pátrio, para permitir a comparação com o Direito Português:

$\left.1^{\circ}\right)$ Só pode ser alegada por pessoa dotada de legitimação ${ }^{39}$. O artigo 152 é claro neste particular, todavia não se assemelha ao correlato 287 do Código Civil Português de 1966 no que diz respeito ao prazo neste disposto.

29) Produz o ato anulável os efeitos enquanto não anulado por sentença. Idêntico entendimento no Direito Português.

$\left.3^{\circ}\right)$ Os terceiros não podem se manifestar, exceto se legitimados, todavia o artigo 148 estabelece o direito dos terceiros, disciplinando a 'lei brasileira em linha diferente da portuguesa, pelo exposto no artigo 288 , $\mathrm{n}^{\circ} \mathbf{4}$, do CCP.

$\left.4^{\circ}\right)$ Pode ser sanada pela ratificação ou decurso de tempo

O saneamento é a característica do ato urídico anulável.

A primeira saneadora analisada é a ratificação, cujo conceito, na doutrina, muito se assemelha ao Português, ou seja, é atitude confirmatória de quem poderia atacar o ato

e contrário, manifesta sua vontade no 
sentido de dar-lhe validade, ou repetindo-o, ou reiterando a declaração de vontade, ou atitude, inequívoca, neste sentido.

Assim exposta, aproxima-se da confirmação, todavia é preciso ter em mente que a doutrina portuguesa, muito embora haja discordância, entende a confirmação como ato unilateral. E neste sentido, o texto do C.C.B. talvez inibisse de se considerar conceitos similares, quando diz: "pode ser ratificado pelas partes" (art. 148).

A bem da verdade, a doutrina, em geral, tem considerado a ratificação também como ato unilateral ${ }^{40}$.

Evitando discussões, mas argumentando a similitude dos dois regramentos, pelo menos nas suas finalidades, é possível afirmar que a ratificação tácita, ou seja, aquela em que o devedor cumpre a obrigação e, portanto, inequivocamente demonstra sua vontade seria, em tese, a confirmação explicada pela doutrina portuguesa ${ }^{41}$.

Por outro lado, o decurso do tempo também saneia o ato viciado, convalidando-o. O não exercício do direito no prazo, tornao válido. De certa forma, aproxima-se da ratificação tácita, ou, como preferem alguns autores, é ratificação presumida ${ }^{42}$.

$\left.5^{\circ}\right)$ As causas de anulabilidade são os vícios da vontade e a incapacidade, com a ressalva, já feita, das diferenças de disciplinação da capacidade do agente nas duas legislações.

6ㅇ) A conversão - em tese, a exemplo do já mencionado no capítulo anterior, a anulabilidade admite a conversão.

$\left.7^{\circ}\right)$ A redução dos negócios jurídicos. está regulado no artigo 153 , já citado anteriormente. Portanto, situação idêntica a de Portugal.

8) Sem efeito retroativo - identificandose com a legislação portuguesa. Todavia reitera-se o afirmado quanto aos incapazes. Entretanto, traz regra neste sentido a diferença é de caráter específico.

Fica evidenciado que, em linhas gerais, há similitude no tratamento do tema. Por evidente, há distinção ao se especificar a matéria, mas, em tese, sem particularizar, as duas legislações se aproximam.

244

\section{Conclusão}

Fica evidenciado, de um lado, a evolução, exigindo mudanças; de outro, a dificuldade em superar obstáculos.

O conceito de ato jurídico/negócio jurídico tem avançado na doutrina e haverá de se refletir na legislação.

Já foi superada a fase da vontade como essência do negócio jurídico, e isto transparece na medida em que as legislações arrolam os vícios da vontade dentre as causas de anulabilidade, não entre as de nulidade. Fica evidenciado, igualmente, que os casos de anulabilidade dependem da estrutura do ordenamento jurídico, eis que está estruturada na conveniência.

O foco da análise dos dois sistemas, Português e Brasileiro, é semelhante.

Desta feita, reitera-se os ensinamentos de Pontes de Miranda, pois concluímos que, sem a distinção entre existência/eficácia; existência/validade, fica muito difícil, pelo menos cientificamente falando, explicar a conversão dos atos jurídicos nulos e o que não dizer quanto à fundamentação do negócio jurídico condicional.

\section{Notas}

${ }^{1}$ Costa, Mário Júlio de Almeida. Enquadramento Histórico do Código Civil Português. Boletim da Faculdade de Direito de Coimbra. Coimbra, Coimbra Editora, 1961. Vol. XXXVII, p. 147.

2 Cruz, Guilherme Braga. A Formação Histórica do Moderno Direito Privado Português e Brasileiro. Rev. da Faculdade de Direito de São Paulo. 1955, Vol. L, p. 35.

${ }^{3}$ Cruz, Guilherme Braga. Op. cit., p. 43.

${ }^{4}$ Ibidem, p. 44-5.

5 Costa, Mário Júlio de Almeida. Op. cit., p. 151.

6 Pinto, Carlos Alberto da Mota. Teoria Geral do Direito Civil. $3^{2}$ ed. Coimbra, Coimbra Editora, 1985. p. 6-7. Importante observar, porém, a distinçào referida pelo autor entre coisas móveis e imóveis, face ao disposto no artigo 29/CC.

7 Gonçalves, Luiz Cunha. Tratato de Direito Civil em Comentário ao Código Civil. São Paulo, Max Limond, 1929. p. 389.

${ }^{8}$ Moreira, Guilherme Alves. Instituiçós do Direito Civil Português. Coimbra, 1907. Vol. 1º, p. 5-9.
9 Gonçalves, Luiz da Cunha. Op. cit., p. 397.

Idem. Princípios de Direito Civil Luso-Brasileiro. São Paulo, Max Limonad, 1951. Vol. I, p. 247.

${ }^{10}$ Decreto $\mathrm{n}^{\circ} 1$ de 25 de dezembro de 1910, artigos $8^{\circ}$, $9^{\circ}, 10^{\circ}, 17^{\circ}, 54$ a 56 , citado por Gonçalves, Luis Cunha. Op. cit. p. 390

${ }^{11}$ Ferreira, José Dias. Código Civil Português Anotado. Lisboa, 1870. p. 28: "Era corrente que as formalidades estabelecidas no intuito de authenticar os actos jurídicos, não deviam exigir-se com o rigor sacramental do direito romano, onde a falta de um gesto fazia perder uma questão".

12 Ibidem. p. 31: "Deu portanto o Código arbítrio aos tribunais para julgarem a nullidade de um acto jurídico só pela falta de uma rubrica exigida na lei, ou por outra qualquer falta insignificante. Cremos, porém, que os tribunais não usarão d'esse arbitrio na latitude que lhes é concedida por este artigo do código." 13 Gonçalves, Luiz Cunha. Tratado de Direito Civil em Comentarios a Collgo Civil. Sao Paulo, Max Limonad, 1928. p. 388 Corigo Civil. Sio Paylo, Max Lima, embora detivesse a verdade, năo soube responder às críticas que 14 .

14 Ibidem. p. 295.

15 Conversão não se confunde com revalidação, já que não é o ato nulo revalidado que produz efeitos, mas é o aproveitamento do possivel a constituir nova figura, entre ambas existe somente $o$ nexo causal, isto $\dot{e}$ conversão efetua-se a partir da anulação do ato.

16 Pinto, Carlos Alberto da Mota. Op. cit., p. 608-9. $O$ autor refere as opiniōes distintas de Galvão Teles e M. de Andrade sobre o tema. Para o primeiro a categoria dos atos inexistentes é eliminável, enquanto o segundo sustenta a autonomia e o interesse prático da classificação.

17 Ibidem. p. 608

18 Miranda, Pontes de. Tratado de Direito Privado. $2^{\underline{a}}$ ed. Rio de Janeiro, Borsi, 1954. Tomo IV, p. 29:

"O nulo é ato que entrou embora nulamente, no mundo juridico. Também entra, e menos débil, no mundo juridico o suporte fáctico do negócio jurídico anulável. Nulo e anulável existem. No plano da existência ( = entrada no mundo jurídico) não há distinguilos. Toda a distinçáo só se pode fazer no plano los. Toda a distinção so se pode fazer no plano da
validade. Se disséssemos que aquele não existe, confunvalidade. Se dissessemos que aquele não existe, confun-
di-lo-íamos com o inexistente; se disséssemos que nulo di-lo-iamos com o inexistente; se dissessemos que nulo é o que não tem efeitos, transplantariamos ao plano da eficácia problema que só há de ser posto e resolvido no plano da validade. Trata-se de distinçào interna ao plano da validade,

Assim, na verdade, evita-se a confusão entre inexistênAssim, never.

19 Observa-se que, na doutrina brasileira, existem au19 Observa-se que, na doutrina brasileira, existem au-
tores que negam importância à distinção entre inexistores que negam importância à distinção entre inex.
tentes $\mathrm{e}$ inválidos, por exemplo, Silvio Rodrigues. tentes e inválidos, por exemplo, Sílvio Rodrigues. Rodrigues, Sílvio. Direito Civil. 5ª ed. São Paulo, Sarai-
va, 1974. Vol. 1, p. 261-2.
${ }^{20}$ Rodrigues, Sílvio. Op. cit., p. 255.

21 Pereira, Caio Mario da Silva. Instituif̧óes de Direito Civil. 5ª ed. São Paulo, Forense, 1978. Vol. 1, p. 549. "E a nulidade e sanção para a ofensa à predeterminação legal".

22 Ibidem, p. 547: "Variando as determinaçōes e exigências da lei, com elas varia o grau de ineficácia, que pode atingir à imperfeição, ou não, como pode abraçar a integridade do ato, ou apenas uma parte dele.

Segundo estas oscilações, há três categorias de atos ineficazes, que serão objeto de nossas imediatas ponderações: uma primeira, referente à sua nulidade, quando em grau mais sensível o ordenamento jurídico é ferido, sendo maior e, ipso facto, mais violenta a reação; uma segunda, anulabilidade, cuja estrutura se prende a uma desconformidade que a própria lei considera menos grave, motivadora de uma reação menos extrema e a terceira, inexistência, em que se verifica a ausência de elementos constitutivos do negócio jurídico, de tal forma que se não chega a formar".

23 Observação exaustivamente examinada por Pontes de Miranda no Tomo IV do Tratado de Direito Privado, já referido.

${ }^{24}$ Pronunciam-se neste sentido, entre outros: Gomes, Orlando. Introduşão ao Direito Civil. Rio de Janeiro, Forense, p. 408.

1979. p. 383-5.

de Direito Civil. São Paulo, Saraiva, Pereira, Caio Mario da Silva. Op. cit., p. 551.

${ }^{25}$ Alarcão, Rui de. Efeito da Confirmação dos Negócios Anuláveis. Boletim da Faculdade de Direito da Universidade de Coimbra, 1978. Vol. LIV, p. 70: "Dir-se-ia anulável o negócio afectado por um vício genético que o priva, em regra retroactivamente, dos efeitos a que se destina, se a pessoa ou pessoas para tanto legitimadas assim o requererem ou declararem".

26 Moreira, Guilherme Alves. Instituiçôes de Direito Civil. Coimbra, 1907. Vol. 1ํ, p. 514:

"A falta de efficacia normal do negócio jurídico, em virtude da qual elle pode deixar de ter os effeitos que segundo o direito obejectivo devia produzir, tem em geral as seguintes causas: incapacidade pessoal do exercicio de direitos em virtudes da menoridade, de interdicção ou do casamento; não serem auctorizados devidamente para os negócios juridicos os incapazes, quando tenham de manifestar a sua vontade, ou os que representantes: vícios da vontade determinados pelo erro, pelo dolo ou pela violência".

27 Gonçalves, Luiz Cunha. Princípios de Direito Civil Luso-Brasileiro. São Paulo, Max Limonad, 1951. Vol. 1, p. 249:

"Há um caso especial, porém, no qual a nulidade relativa pode ser argüida por quem não foi parte do acto: é o da doção feita por homem casado à sua concubina, doação que só pode ser anulada a pedido da mulher legítima (v. cit Código, art. 1480)"

${ }^{28}$ Moreira, Guilherme Alves. Op. cit., p. 516. 
29 Gonçalves, Luiz Cunha. Tratado de Direito Civil em Comentário ao Código Civil. 1929. Vol. 1, p. 402.

30 Pinto, Carlos Alberto da Mota. Teoria Geral do Direito Civil. $3^{3}$ ed. Coimbra, Coimbra Editora, 1985. p. 614-5.

"Assim, se $A$ vende a $B$ um objeto, por negócio anulável (p. ex., por incapacidade) e, antes da confirmação, vendo o mesmo objeto a $C$, a confirmação da primeira
venda torna a segunda viciada por ilegitimidade do venda torna a segunda viciada por
vendedor (venda de coisa alheia)".

vendedor (venda de coisa alheia)".
31 Alarcão, Rui de. Op. cit., p. 75-6

"Pois a eficácia do negócio anulável é apenas provisória ou interina - uma eficácia precária, sujeita ao risco de ser removida ex tunc; ao passo que, depois da confimação, esse risco desaparece e os efeitos do negócio passam a ser definitivos".

32 Pinto, Carlos Alberto da Mota. Op. cit., p. 610: "O negócio anulável, não obstante a falta ou vício de um elemento interno ou formativo, produz os seus

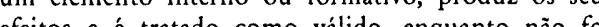
julgeda procedente uma acáo de anulaçäo; exercido, julgada procedente uma açáo de anulaçao, exercido, mediante esta aço, o direito pertacivo de anular, pertencente a uma das partes,
retroativamente destruídos".

${ }^{33}$ Alarcão, Rui de. Op. cit., p. 70:

"A anulabilidade, todos o sabem, é uma figura centra

da teoria da ineficácia (latu sensu) do negócio jurídico,

figura que no direito contemporâneo se tem desenvol-

vido em detrimento da nulidade, por se revelar mais dúctil e flexível que esta, mais ajustada aos ditames $\mathrm{d}$ autonomia privada e da conservação da actividade negocial, e mais apta, por tudo isso, a satisfazer as necessidades ou os interesses da vida jurídica".

34 Ibidem. p. 71.

35 Neste aspecto há divergência doutrinária. Pensam neste sentido Mota Pinto e Rui de Alarcão, entre outros; vejam-se obras citadas.

${ }^{36}$ Alarcão, Rui de. Op. cit., p. 79-82.

${ }^{37}$ Miranda, Pontes de. Op. cit., p. 33:

"A anulabilidade é a não-validade, dependente de decretação que reduza a nada o negócio jurídico e os seus efeitos, decretação subordinada a não estar prescrita ação de anulaça A decretaça da nulidade desconsitui o negócio jurídico existente a decretaço da anulacalo ção desconsticu titui-the a eficácia. Aqui, ponto da distinção, no direit

38 Pereira, Caio Mario da Silva. Op. cit., p. 552:

"Não tem o mesmo alcance da nulidade, nem traz mesmo fundamento a anulabilidade do negócio juríd co. Nela se não vislumbra o interesse público, porém a mera conveniência das partes, já que na sua instituição o legislador visa à proteção de interesses privados".

39 Pereira, Caio Mario da Silva. Op. cit., p. 552.

${ }^{40}$ Miranda, Pontes de. Op. cit., p. 240:

"A ratiticação é negócio jurídico unilateral, oriundo de manifestação de vontade não receptícia...".
41 Orlando Gomes, por exemplo, utiliza a expressão confirmação no sentido de ratificação.

Gomes, Orlando. Contratos. Rio de Janeiro, Forense, $7^{\mathrm{a}}$ ed. 1979. p. 233.

Este fato, e mais a análise do sentido do ato, leva-nos a entender que, pelo menos no sentido teleológico, há identificação nos dois sistemas. Ressalvado, evidentemente, o particularismo.

42 Pereira, Caio Mario da Silva. Op. cit., p. 553.

\section{Bibliografia}

Alarcão, Rui de. Efeitos da Confirmação dos Negócios Anuláveis. Boletim da Faculdade de Direito de Coimbra, Coimbra. 1978. Vol. LIV, p. 69.

Andrade, Manuel de. Sobre a Recente Evolução do Direito Privado Português. Boletim da Faculdade de Direito da Universidade de Coimbra, Coimbra, 1946. Vol. XXII, p. 284

Carvalho, Orlando. Teixeiras de Freitas e a Unificação do Direito Privado. Boletim da Faculdade de Direito da Universidade de Coimbra, Coimbra, 1984. Vol. LX, p. 1.

Costa, Mário Júlio de Almeida. Enquadramento Histórico do Código Civil Português. Boletim da Faculdade de Direito da Universidade de Coimbra, Coimbra, 1961. Vol. XXXVII, p. 138.

Cruz, Guilherme Braga. A Formação Histórica do Moderno Direito Privado Português e Brasileiro. São Paulo, Revista de Direito da Universidade de São Paulo. 1955. Vol. L, p. 32.

Ferreira, José Dias. Código Civil Português Anotado. Lisboa, 1870 . Vols. I e II.

Gomes, Orlando. Introduşão ao Direito Civil. Rio de Janeiro, Forense, p. 408.

-. Novas Questốes de Direito Civil. São Paulo, Saraiva, 1979. p. 383-5.

--. Contratos. $7^{2}$ ed. Rio de Janeiro, Forense, 1979.

Gonçalves, Luís Cunha. Tratado de Direito Civil em Comentário ao Código Civil. São Paulo, Max Limonad, 1929.

--. Princípios de Direito Civil Luso-Brasileiro. São Paulo, Max Limonad, 1951. Vol. 1.

Lima, Fernando Andrade Pires de e outro. Código Civil Anotado. Coimbra, Coimbra Editora, 1967. Vol. I, art. 1ำ 761 .

Marques, Mario Reis. O Liberalismo e a Codificação do Direito Civil em Portugal. Boletim da Faculdade de Direito da Universidade de Coimbra, Coimbra, 1986. Vol. XXIX, p. 1. Suplemento.

Miranda, Pontes de. Tratado de Direito Privado. $2^{2}$ ed. Rio de Janeiro, Borsoi, 1954. Tomo IV.
Moreira, Guilherme Alves. Instituifões de Direito Civil Português. Coimbra, 1907. Vol. 1.

Pereira, Caio Mario da Silva. Instituições de Direito Civil. $5^{3}$ ed. Rio de Janeiro, Forense, 1978.

Pinto, Carlos Alberto da Mota. Teoria Geral do Direito Civil. $3^{2}$ ed. Coimbra, Coimbra Editora, 1985.

Proença, José Carlos Brandão. A Resoluşão do Contrato no Direito Civil (do enquadramento e do regime). Coimbra, 1982.

Rodrigues, Silvio. Direito Civil. São Paulo, Saraiva, 1974. Vol. 1.

Serra, Adriano Paes da Silva. A Revisão Geral do Código Civil. Boletim da Faculdade de Direito da Universidade de Coimbra, Coimbra, 1946. Vol. XXII, p. 451.

Silva, Clóvis Veríssimo do Couto. O Direito Civil Brasileiro em Perspectiva Histórica e Visão de Futuro. Porto Alegre, AJURIS, (40): 128, jul./1987.

Legislação

Código Civil Português de 1867.

Código Civil Português de 1966.

Código Civil Brasileiro de 1916. 